\title{
ANALISIS KURS, INFLASI DAN KONSUMSI BERAS PERKAPITA TERHADAP IMPOR BERAS DI INDONESIA
}

\author{
Chica Kurniawan ${ }^{1},{ }^{2}$ Khairil Anwar, ${ }^{3}$ Fanny Nailufar \\ chica.170420025@mhs.unimal.ac.id \\ khairil.anwar@unimal.ac.id \\ fannynailufar@unimal.ac.id
}

${ }^{1,2,3}$ Fakultas Ekonomi dan Bisnis Universitas Malikussaleh, Lhokseumawe

Jl. Kampus UNIMAL Bukit Indah, Kabupaten Aceh Utara, Aceh 24355

Received:September 2021; Accepted:September 2021; Published:September 2021

\begin{abstract}
This study analyzed the relationship between exchange rates, inflation, and rice consumption per capita on rice imports in Indonesia. The data used in this study are secondary data during the 2007-2018 period and by 6 main rice exporting countries. The analysis tool used was the panel data analysis method (a combination of cross-section and time-series) with the Ordinary Least Square (OLS) approach. The results indicated that the relationship between exchange rate and inflation did not affect the level of rice imports in Indonesia because the exchange rate and inflation cannot influence consumption and import needs in Indonesia. Meanwhile, per capita rice consumption also did not have a significant effect on rice imports in Indonesia because there has been a change in consumption patterns at the head of household level in Indonesia so that the level of rice consumption continues to decline each year.
\end{abstract}

Key words : Exchange Rate, Inflation, Consumption, Import, Panel Data

\section{PENDAHULUAN}

Indonesia adalah negara agraris yang menggunakan beras sebagai makanan pokoknya, di Indonesia sendiri bahkan menganggap bahwa belum bisa seseorang dianggap sudah makan apabila belum memakan nasi. Nasi sendiri adalah salah satu jenis olahan dari beras. Atas dasar inilah mengapa masyarakat Indonesia masih banyak bergantung dengan beras sebagai makanan pokoknya. Bahkan kepala badan pusat urusan logistik Sutarto Alimoeso pernah mengatakan dalam wawancaranya dalam acara Mata Indonesia bahwa 95\% orang Indonesia bergantung kepada beras sebagai makanan pokok.

Padahal pada zaman dahulu orang Indonesia memiliki makanan pokok sesuai dengan keadaan dan karakteristik wilayahnya masing-masing, misalnya di Jawa Timur dan Jawa Tengah banyak masyarakat yang menggunakan jagung sebagai bahan makanan pokok contoh lain di wilayah Papua Maluku dan kebanyakan masyarakat Indonesia di wilayah di Indonesia timur menggunakan sagu sebagai bahan makanan pokok. Namun seiring berkembangnya zaman 
banyak hal yang berubah khususnya dari pola konsumsi masyarakat, dan mengikuti daerah-daerah yang lebih maju serta mengubah pola konsumsi makanan mereka yakni berubah menjadi beras. Hal ini menyebabkan konsumsi beras di Indonesia terus meningkat setiap tahunnya, sehingga membuat beras menjadi bahan makanan pokok yang sangat populer dan paling dibutuhkan di Indonesia.

Menurut data oleh Badan Pusat Statistik (BPS) peningkatan kebutuhan akan konsumsi beras di Indonesia setiap tahunnya tidak dibarengi dengan produksi beras yang cukup di dalam negeri. Ditengarai, ada beberapa hal yang menyebabkan hal ini terjadi, salah satunya yakni pertumbuhan penduduk di Indonesia yang terlalu tinggi namun tidak dibarengi dengan peningkatan produktivitas produksi padi di Indonesia.

Menurut data Litbang Pertanian, lahan pertanian di Indonesia pada tahun 2018 luasnya sekitar 7,1 juta hektar. Jumlah yang terbilang sangat luas jika dibandingkan dengan negara-negara tetangga. Namun luas lahan yang terbilang sangat luas tersebut sampai saat ini masih belum bisa digunakan secara optimal. Misalnya saja dalam hal produksi beras Indonesia sampai saat ini masih terus mengimpor beras dari luar negeri untuk bisa memenuhi kebutuhan akan konsumsi beras domestik.

Tabel 1. Data Beras yang di Impor dari Enam Negara Eksportir Utama Periode 2010-2018

\begin{tabular}{cc}
\hline Tahun & $\begin{array}{c}\text { Jumlah Impor } \\
\text { (Ton) }\end{array}$ \\
\hline 2010 & 680736,1 \\
2011 & 2725915,7 \\
2012 & 1662257,4 \\
2013 & 374098,3 \\
2014 & 764692,1 \\
2015 & 670767,5 \\
2016 & 1264441,5 \\
2017 & 160173,4 \\
2018 & 1901007,7 \\
\hline
\end{tabular}

Sumber: Badan Pusat Statistik, 2018

Dari data Tabel 1, dapat kita lihat bahwa pada periode 2010-2018 jumlah beras yang diimpor keenam negara eksportir utama tersebut bersifat fluktuatif. Kenaikan signifikaan terjadi pada tahun 2011 yakni pada tahun 2010 jumlah impor senilai 680.736,1 kg meningkat hingga 2.725.915,7 ton pada tahun 2011. Namun, secara umum sejak tahun 2010 hingga tahun 2018 Indonesia cenderung mengalami kenaikan jumlah impor beras setiap tahunnya. Hal ini dapat mengidentifikasikan beberapa hal, salah satunya ialah tingkat produksi beras dalam negeri tidak mampu memenuhi kebutuhan akan konsumsi beras tiap tahunnya. Pada periode 2015 hingga 2016 tingkat impor beras mengalami kenaikan secara spesifik, namun pada tahun 2017 tingkat import beras mengalami penurunan secara signifikan. 


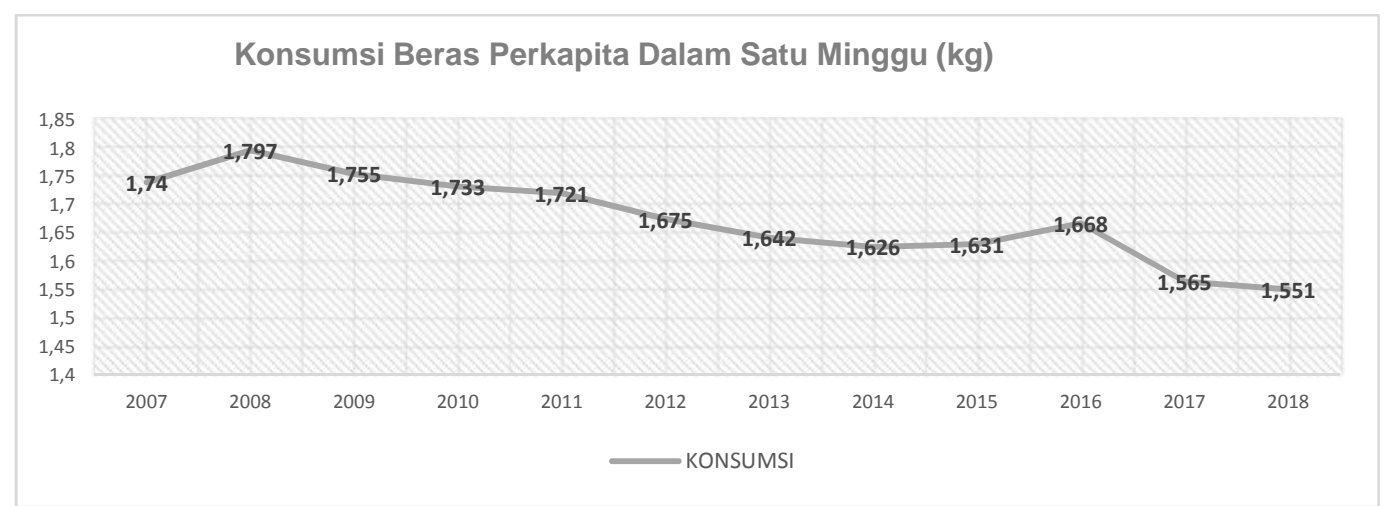

Sumber: Badan Pusat Statistik 2018

Gambar 1. Rata-Rata Konsumsi Beras Perkapita Dalam Seminggu Periode 2010-2018 di Indonesia

Dari data pada Gambar 1, dapat kita perhatikan bahwa konsumsi beras lokal perkapita nasional antara tahun 2010 hingga tahun 2018 cenderung mengalami penurunan. Secara teori hal ini dapat terjadi karena beberapa faktor, misalnya kurang terserapnya produk beras lokal dikalangan para petani ataupun konsumen yang lebih memilih beras impor. Penurunan konsumsi beras lokal perkapita nasional terbesar terjadi tahun 2011 ketahun 2012 yakni dari $1.732 \mathrm{~kg}$ per kapita $1.675 \mathrm{~kg}$ per kapita.

Dalam konsep nilai tukar, nilai tukar bisa didefinisikan sebagai harga dari mata uang asing kedalam mata uang dalam negeri ataupun domestik. Hal ini berarti bahwa eskalasi kurs menunjukan eskalasi valas yang berdampak pada depresiasi rupiah, hal ini juga berlaku sebaliknya.

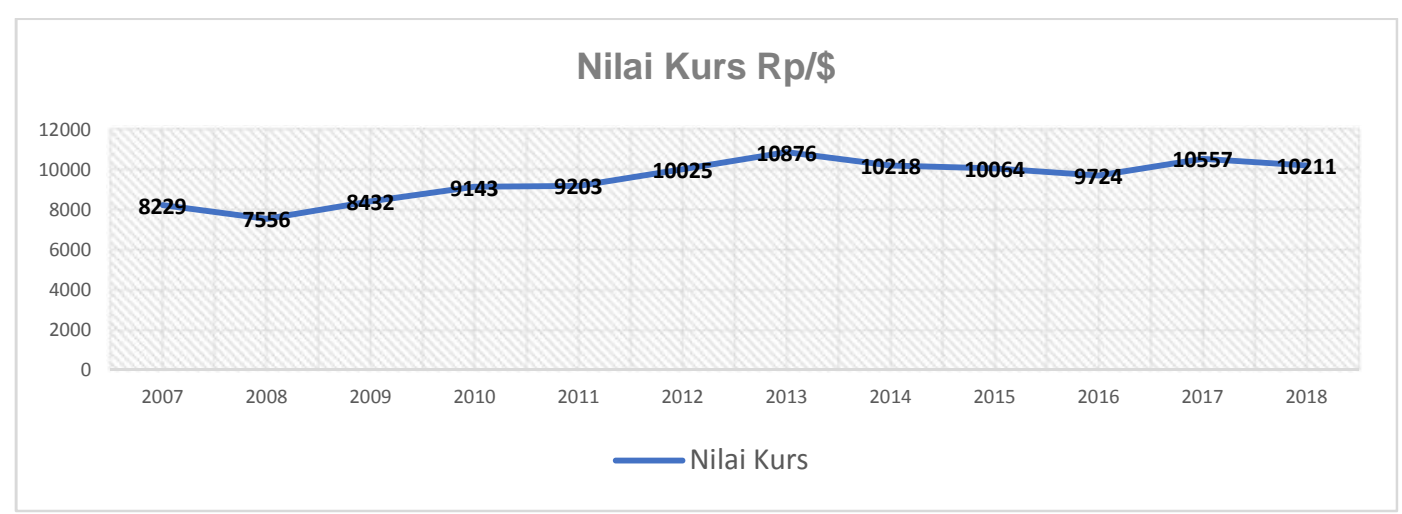

Sumber: Badan Pusat Statistik 2018

Gambar 2. Kurs Rupiah Terhadap Dolar Periode 2010-2018 Indonesia

Dari data pada Gambar 2 dapat kita lihat bahwa nilai tukar rupiah atas valas bervariasi. Salah satu acuan mata uang rupiah atas valas adalah dolar Amerika. Kurs rupiah terhadap dollar Amerika setiap tahunnya cenderung mengalami kenaikan. Pada tahun 2010 rupiah berada di angka Rp.8.991 per dollar. Sedangkan tahun 2018 senilai Rp.14.481 per dolar.

Ada beberapa penyebab naiknya permintaan dolar misalnya adalah 
tingginya permintaan, dalam keadaan ini para investor akan lebih tertarik menanamkan kekayaannya kedalam bentuk dollar Amerika Serikat. Hal inilah yang menyebabkan Dollar Amerika Serikat terus mengalami penguatan atau apresiasi yang sebaliknya malah menyebabkan rupiah mengalami pelemahan atau depresiasi.

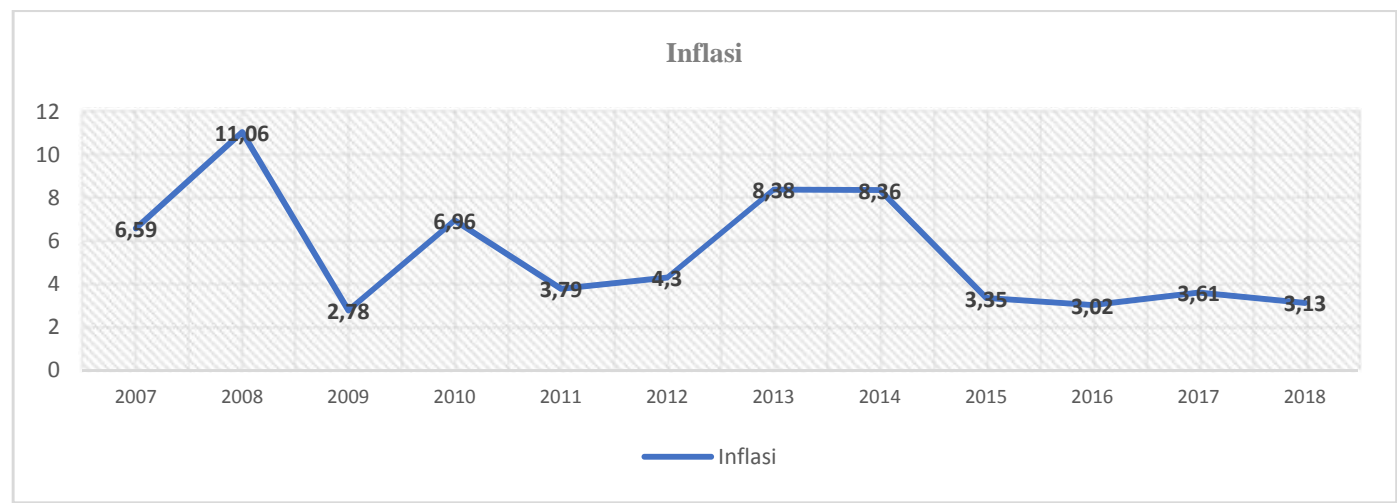

Sumber: Badan Pusat Statistik 2018

Gambar 3. Persentase Nilai Inflasi Indonesia Periode 2007-2018

Berdasarkan data pada Gambar 3, dapat kita lihat bahwa nilai inflasi di Indonesia pada tiap tahunnya terus mengalami fluktuasi. Pada tahun 2011 inflasi di Indonesia rata-rata mencapai 3,02\% dengan nilai tertinggi terjadi pada bulan juni yang mencapai $0,69 \%$. Sedangkan pada tahun 2018 nilai inflasi di Indonesia mencapai $3,13 \%$ dengan poin tertinggi terjadi pada bulan mei yang menyentuh angka $0,68 \%$. Tingkat inflasi tertinggi pada periode tersebut terjadi pada tahun 2012 ke tahun 2013 yakni dari 4,3\% ke angka 8,34\%.

Pada penelitian sebelumnya ada beberapa penelitian yang juga meneliti dengan variabel yang serupa. Seperti Penelitian yang dilakukan oleh (Yulianto, 2016) yang berjudul pengaruh nilai tukar Rupiah harga beras internasional dan produksi beras dalam negeri terhadap volume impor beras di Indonesia. Berbeda dengan penelitian sebelumnya yang pada penelitian tersebut menggunakan model analisis regresi linear berganda, sedangkan pada model penelitian ini menggunakan model data panel.

\section{METODE PENELITIAN}

Untuk menganalisis pengaruh antara nilai kurs inflasi dan konsumsi beras perkapita terhadap impor beras di Indonesia dianalisis melalui model data panel. Pendekatan dengan model data panel mencakup dua uji yaitu Uji Hausman dan Uji Chow. Model tersebut perlu dianalisis melalui alat analisis yang meliputi:

\section{Uji Normalitas}

Uji normalitas merupakan langkah uji yang dilakukan apakah data yang diuji telah terdistribusi secara normal atau tidak normal. Dalam menguji Uji Normalitas dapat digunakan dengan Analisis Grafik dan Anlisis Statistik.

\section{Pengujian Autokorelasi}

Uji autokorelasi asumsi adalah uji yang digunakan untuk mengetahui apakah dalam sebuah model regresi linear ada korelasi antara kesalahan 
pengganggu pada periode $\mathrm{t}$ dengan kesalahan pengganggu pada periode $\mathrm{t}-1$ (sebelumnya). Jika terjadi korelasi, maka dinamakan problem autokorelasi. Untuk mengetahui apakah sebuah data terdapat asumsi autokorelasi, dapat dilakukan uji statistik melalui uji Durbin-Watson (DW Test), lalu selanjutnya adalah membandingkan dengan tabel DW.

\section{Pengujian Multikolinearitas}

Uji Multikolinearitas yaitu adanya hubungan yang kuat antara variabel variabel independen dalam persamaan regresi. Adanya mengakibatkan terjadinya inkonsistensi estimasi, sehingga mengarahkan kesimpulan untuk menerima hipotesis nol. Hal ini menyebabkan koefesien hasil regresi tidak signifikan serta sangat sensitive terhadap perubahan data (Gujarati,2006).

\section{Uji Estimasi}

\section{Uji Parsial (Uji-T)}

Uji parsial bertujuan untuk menguji besaran dampak variabel independen kepada variabel dependen dengan membandingkan t-hitung dengan t-tabel (Mayes, Yusuf and Tambunan, 2015) dengan cara membandingkan T-Statistik dengan T-Tabel.

\section{Uji Simultan (Uji-F)}

Uji Simultan atau uji Bersama-sama adalah suatu uji estimasi untuk melihat apakah masing-masing variable bebas memiliki pengaruh terhadap variable terrikat secara Bersama-sama dengan cara membandingkan antara FStatistik dengan F-Tabel.

\section{Uji Estimasi R-Square}

Pengujian koefisien determinasi $\left(\mathrm{R}^{2}\right)$ dilakukan untuk melihat seberapa besarkah hubungan antara variabel bebas nilai kurs inflasi dan tingkat konsumsi beras per kapita dalam seminggu terhadap variabel terikat tingkat impor beras di Indonesia. untuk mengetahui seberapa besar hubungannya dapat dilihat dari nilai adjusted $\mathrm{R}$ square.

\section{Hausman Test dan Chow Test}

Hasil dari regresi yang menggunakan Fixed Model Effect (FEM) ataupun Common Effect Model (CEM). Uji Chow digunakan untuk memilih antara Common Effect Model atau Fixed Effect Model.

\section{HASIL DAN PEMBAHASAN \\ Hasil Penelitian \\ Hasil Uji Normalitas}

Dari gambar dibawah ini dapat dilihat bahwa grafik histogram dapat membentuk bentuk pola distribusi simetris, dengan demikian maka dapat disimpulkan bahwa hasl dari residual tersebut adalah normal. Hasil uji normalitas juga dapat dilihat dengan cara membandingankan antara nilai probabilit JarqueBere dengan nilai signifikan 5\% dengan ketentuan apabila nilai Jarque-Bere $<5 \%$ maka residual distribusi tidak normal atau nilai probability Jarque-Bere $>5 \%$ maka residualnya berdistribusi normal. Adapun hasil dari uji normalitas diatas menunjukan bahwa nilai probability Jarque-Bere $>5 \%$ yaitu sebesar $0.997193>$ 0,5. Maka dapat disimpulkan bahwa distribusi data variabel berdistribusi secara 
normal.

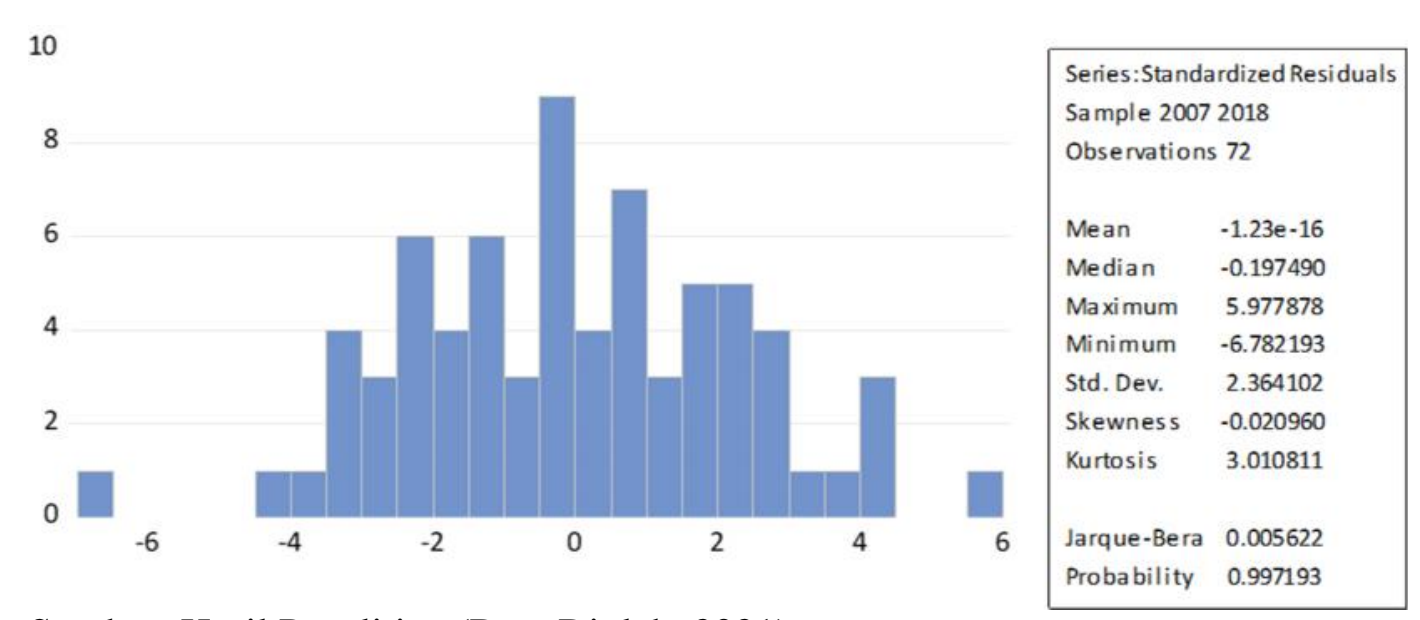

Sumber: Hasil Penelitian (Data Diolah, 2021)

Gambar 4. Uji Normalitas

\section{Hasil Pengujian Multikolinearitas}

Uji multikolinearitas adalah uji yang bertujuan untuk menguji apakah suatu model regresi terdapat korelasi antara variabel bebas (independen). Berikut adalah hasi pengujian Uji Multikolinearitas (Multikolinearity Test) pada penelitian ini:

Tabel 2. Hasil Multikolinearitas

$\begin{array}{lrrr}\text { X1 } & 1.000000 & -0.272907 & -0.867524 \\ \text { X2 } & -0.272907 & 1.000000 & 0.365115 \\ \text { X3 } & -0.867524 & 0.365115 & 1.000000\end{array}$

Sumber: Hasil Penelitian (Data Diolah, 2021)

Tabel 2 menunjukkan bahwa nilai korelasi matriks antara 3 variabel tersebut kurang dari 0,80. Maka dapat dikatakan bahwa tidak terdapat masalah multikolinearitas dalam model prediksi.

\section{Hasil Uji Autokorelasi}

Uji autokorelasi dalam penelitian ini dilakukan dengan menggunakan metode Durbin-Watson (DW). Dari model terbaik dalam regresi yang terbentuk dari model Fixed Effect, dapat dilihat bahwa nilai DW dari persamaan regresi yang terbentuk adalah sebesar 1.498314. Sedangkan nilai tabel Durbin-Watson dengan nilai $\mathrm{n}=72$ dan $\mathrm{k}=3$, maka diperoleh nilai $\mathrm{dL}=1,5323$ dan $\mathrm{dU}=1,7054$ sehingga nilai 4-dU $=4-1,7054=2,2946$, maka nilai DW dari model regresi yang terbentuk pada penelitian ini berada pada area bebas autokorelasi karena nilai Durbin-Watson berada pada angka $>1$ dan $<3$ (1.572090). 
Tabel 3. Hasil Uji Autokorelasi

\begin{tabular}{lrlr}
\hline \hline & & & \\
Root MSE & 2.347627 & R-squared & 0.729109 \\
Mean dependent var & 8.285137 & Adjusted R-squared & 0.694710 \\
S.D. dependent var & 4.542229 & S.E. of regression & 2.509719 \\
Akaike info criterion & 4.794687 & Sum squared resid & 396.8175 \\
Schwarz criterion & 5.079271 & Log likelihood & -163.6087 \\
Hannan-Quinn criter. & 4.907981 & F-statistic & 21.19574 \\
Durbin-Watson stat & 1.498314 & Prob(F-statistic) & 0.000000 \\
\hline \hline
\end{tabular}

Sumber: Hasil Penelitian (Data Diolah, 2021)

\section{Hasil Uji Chow}

Uji Chow digunakan untuk memilih antara Common Effect Model atau Fixed Effect Model. Berikut hasil Uji Chow pada tabel berikut :

Tabel 4. Uji Chow

\begin{tabular}{|l|r|r|r|}
\hline Redundant Fixed Effects Tests & \\
\hline Equation: Untitled & & \\
\hline Test cross-section fixed effects & & \\
\hline & & & \\
\hline
\end{tabular}

Sumber: Hasil Penelitian (Data Diolah, 2021)

Berdasarkan hasil pengujian yang ditunjukkan oleh table 4 diatas, diketahui bahwa baik nilai p-value > maupun chi-square kedua model siginifikan. Hal ini sesuai dengan kriteria pengujian yang telah dijabarkan bahwa hasil dari Uji Chow yakni pada probability chi-square sebesar 0.0000 lebih kecil dari 0.05 sehingga dapat disimpulkan pada penelitian ini memilih Fixed Effect Model sebagai model regresi yang cocok.

\section{Hasil Uji Hausman}

Hasil dari regresi yang menggunakan Fixed Model Effect (FEM) ataupun Common Effect Model (CEM) kedua-duanya menunjukkan hasil yang signifikan. Namun kita belum dapat menentukan model mana yang kita gunakan. Oleh karena itu diperlukan uji Hausman untuk mengetahuinya. Adapun hasil pengujian Uji Huasman pada penelitian ini adalah sebagai berikut.

Uji hausman digunakan untuk menentukan apakah Random-Effect atau Fixed-Effect yang digunakan, kita harus membandingkan nilai Uji Hausman dengan nilai Chi-Square. Nilai Chi-Square dengan Degree of Freedom sebanyak independent variable yaitu empat dan menggunakan nilai signifikansi $5 \%$. 
Tabel 5. Uji Hausman

Correlated Random Effects - Hausman Test

Equation: Untitled

Test cross-section random effects

\begin{tabular}{lllc}
\hline \hline Test Summary & Chi-Sq. Statistic & Chi-Sq. d.f. & Prob. \\
\hline \hline Cross-section random & 0.000000 & 3 & 1.0000 \\
\hline
\end{tabular}

Sumber: Hasil Penelitian (Data Diolah, 2021)

Berdasarkan variabel individu atas uji t-stat tersebut model Fixed yang mendekati nilai yang memiliki nilai signifikansi mendekati 0,05 . Nilai probability dari F-Staistik senilai 0, 000000 memberikan artian bahwa model Fixed tersebut significant. Nilai adjusdted $\mathrm{R}^{2}$ sebesar 0.694710 memberikan nilai tinggi yang cukup memuaskan, namun Durbin-Watson stat sebesar 1.498314. dengan demikian model yang dipilih adalah Model Fixed Effect.

\section{Pengujian Hipotesis}

\section{Uji Parsial (Uji-T)}

Apabila nilai T-hitung < T-hitung maka variabel independen tersebut mempengaruhi variabel dependen berikut dibawah ini hasil pengujian secara parsial dalam penelitian ini:

Tabel 6. Uji Parsial (Uji-T)

\begin{tabular}{|c|c|c|c|c|c|}
\hline Variabel Bebas & T-Statistik & T-Tabel & Probability & Keterangan & Hipotesis \\
\hline Nilai Kurs & 1.647 .682 & \multirow{3}{*}{166.757} & 0.1044 & Tidak Berengaruh & HO \\
\hline Inflasi & 1.219 .840 & & 0.2271 & Tidak Berengaruh & HO \\
\hline Konsumsi & 1.570 .338 & & 0.1213 & Tidak Berengaruh & HO \\
\hline
\end{tabular}

Sumber: Hasil Penelitian (Data Diolah, 2021)

Berdasarkan pada Tabel 6, dapat kita lihat bahwa variabel nilai kurs memiliki nilai T-hitung $=1.647 .682<\mathrm{T}$-tabel $=1.66757$. Maka H0 diterima yang artinya bahwa variabel nilai kurs tidak berpengaruh terhadap tingkat impor. Selanjutnya variabel tingkat inflasi memiliki nilai T-hitung $=1.219 .840<$ T-tabel $=1.66757$. Maka H0 diterima yang artinya variabel tingkat inflasi tidak memiliki pengaruh terhadap tingkat impor beras di Indonesia.

Selanjutnya variabel rata-rata tingkat konsumsi beras per kapita dalam seminggu memiliki nilai T-hitung $=1.570 .338<\mathrm{T}$-tabel $=1.66757$ maka Terima $\mathrm{H} 0$ yang artinya tingkat konsumsi rata-rata beras berkapita dalam seminggu tidak berpengaruh terhadap tingkat impor beras di Indonesia.

\section{Uji Simultan (Uji-F)}

Uji simultan (uji F) merupakan pengujian variabel independen secara keseluruhan dengan variabel dependen. untuk mengetahui apakah variabel independen secara statistik mempengaruhi variabel dependen yaitu dengan 
melihat nilai $\mathrm{F}$ statistik. Apabila nilai $\mathrm{F}$ hitung $>\mathrm{F}$ tabel maka secara bersamasama variabel independen mempengaruhi variabel independen. Berikut pengujian simultan (uji F) pada penelitian ini:

Tabel 7. Uji Simultan (F-Statistik)

\begin{tabular}{lllll}
\hline F Statistik & F Tabel & Probabilitas & Keterangan & Hipotesis \\
\hline $\mathbf{2 1 . 1 9 5 7 4}$ & 2,740 & 0.000000 & Signifikan & Terima H1 \\
\hline
\end{tabular}

Sumber: Hasil Penelitian (Data Diolah, 2021)

Berdasarkan pada Tabel 7, dapat dilihat bahwa nilai F-hitung $=21.19574$ sementara nilai F-tabel sebesar 2.740 sehingga dapat diketahui bahwa nilai Fhitung $=21.19574>$ F-tabel $=2.740$ maka dapat disimpulkan variabel nilai kurs, inflasi dan rata-rata tingkat konsumsi beras per kapita berpengaruh positif dan signifikan terhadap tingkat impor beras di Indonesia. Hal ini juga bisa dilihat dari tingkat probabilitasnya yang signifikan $0.000000<0.05$.

\section{Uji Determinan R-Square}

Uji ini dilakukan untuk mengetahui seberapakah besaran pengaruh antara ketiga variable bebas terhadap variable terikat.

Tabel 8. Uji Determinan R-Square

Effects Specification

Cross-section fixed (dummy variables)

\begin{tabular}{llll}
\hline \hline & & & \\
Root MSE & 2.347627 & R-squared & 0.729109 \\
Mean dependent var & 8.285137 & Adjusted R-squared & 0.694710 \\
S.D. dependent var & 4.542229 & S.E. of regression & 2.509719 \\
Akaike info criterion & 4.794687 & Sum squared resid & 396.8175 \\
Schwarz criterion & 5.079271 & Log likelihood & -163.6087 \\
Hannan-Quinn criter. & 4.907981 & F-statistic & 21.19574 \\
Durbin-Watson stat & 1.498314 & Prob(F-statistic) & 0.000000 \\
\hline \hline
\end{tabular}

Sumber: Eviews data diolah 2021

\section{Pembahasan}

\section{Hubungan Nilai Kurs Terhadap Impor Beras}

Berdasarkan hasil pengujian secara parsial pada variabel nilai kurs dalam penelitian ini dapat dilihat bahwa nilai kurs tidak berpengaruh terhadap tingkat impor $(\mathrm{T}$-hitung $=1647682<\mathrm{T}$-tabel $=1.66757)$. Secara teori hubungan antara nilai kurs dengan tingkat impor adalah negatif. Dengan kata lain, ketika nilai tukar Dollar Amerika terhadap Rupiah meningkat maka akan menurunkan daya beli importir beras dalam negeri untuk mengimpor beras dari luar negeri sehingga jumlah impor juga akan menurun. 


\section{Hubungan Tingkat Inflasi dan Impor Beras}

Berdasarkan hasil pengujian secara parsial pada variabel inflasi dalam penelitian ini dapat kita lihat bahwa inflasi tidak berpengaruh terhadap impor beras di Indonesia (nilai T-hitung $=1.219 .840<\mathrm{T}$-tabel $=1.66757$ ). Tidak ditemukannya pengaruh antara tingkat nilai inflasi dengan volume impor beras disebabkan karena kebutuhan akan konsumsi tidak selalu tergantung oleh pergerakan inflasi baik meningkat atau stabil. Selain itu permintaan akan suatu komoditas impor yang selalu berubah-ubah setiap waktu sesuai dengan kebutuhan akan komoditas tersebut

\section{Hubungan Konsumsi Beras Perkapita terhadap Impor Beras}

Berdasarkan hasil penelitian yang dilakukan, variabel Penanaman Modal Dalam Negeri (PMDN) terhadap tingkat kemiskinan berpengaruh negatif dan tidak signifikan terhadap tingkat kemiskinan. Hal ini bisa terjadi dikarenakan modal investasi dalam negeri bersifat produktif sehingga melibatkan banyak tenaga kerja sehingga tingkat kemiskinan menurun.

\section{KESIMPULAN}

Berdasarkan analisis yang dilakukan melalui model data panel hasil penelitian menunjukkan bahwa hasil pengujian secara parsial menggunakan data panel model Fixed Efect Model, variabel nilai kurs Rupiah terhadap Dollar Amerika secara parsial tidak berpengaruh terhadap tingkat impor beras di Indonesia. Sedangkan variabel tingkat inflasi secara parsial tidak berpengaruh terhadap tingkat impor beras di Indonesia. Variabel tingkat konsumsi beras ratarata per kapita dalam 1 minggu di Indonesia terhadap tingkat impor beras di Indonesia memiliki pengaruh negatif terhadap impor beras di Indonesia. Semantara itu Berdasarkan hasil pengujian secara simultan menggunakan data panel model Fixed Effect Model nilai kurs, inflasi dan konsumsi beras perkapita berpengaruh terhadap impor beras di Indonesia.

\section{REFERENSI}

Andy F. 2011. Discovering Statistic Using SPSS. Third Edition. London: Sage Publications.

Arifin, S., \& Mayasya, S. 2018. Faktor - Faktor Yang Mempengaruhi Nilai Tukar Rupiah Terhadap Dolar Amerika Serikat. Jurnal Ekonomi-Qu, 8(1),8296. https://doi.org/10.35448/jequ.v8i1.4965

Benny, J. 2013. Ekspor Dan Impor Pengaruhnya Terhadap Posisi Cadangan Devisa Di Indonesia. Jurnal EMBA. 1(4), pp. 1406-1415.

Brianto, D. 2015. Pengaruh Produksi Beras, Impor Beras, Tingkat Konsumsi Beras Terhadap Harga Beras Di Indonesia Tahun 2008-2013. Tesis. UIN Syarif Hidayatullah.

Federico J. Diez \& Gita Gopinath, 2015. The Effects of a Stronger Dollar on U.S. Prices, " Current Policy Perspectives. 15-9, Federal Reserve Bank of Boston.

Dona Agus, I Made; Ayuningsasi, Anak Agung Ketut. 2016. Pengaruh Kurs, 
Harga, dan PDB terhadap Impor Sapi Australia ke Indonesia. E-Jurnal Ekonomi Pembangunan Universitas Udayana. ISSN 2303-0178. Available at: 〈https://ojs.unud.ac.id/index.php/eep/article/view/21737>.

Gujarati, Damodar N. 2007. Dasar-Dasar Ekonometrika, Edisi Ketiga, Jilid Dua. Erlangga: Jakarta.

Herzberg, V., \& Price, S. 2003. Import Prices And Exchange Rate Pass-Through: Theory And Evidence From The United Kingdom. EconPapers. Bank of England Working Papers.

Indrayani, N., \& Swara, I. 2014. Pengaruh Konsumsi, Produksi, Kurs Dollar AS Dan PDB Pertanian Terhadap Impor Bawang Putih Indonesia. E-Jurnal Ekonomi Pembangunan Universitas Udayana, 3(5), 209-218.

Kuswantoro, M. 2017. Analisis Pengaruh Inflasi, Kurs, Utang Luar Negeri Dan Ekspor Terhadap Cadangan Devisa Indonesia. Tirtayasa Ekonomika, 12(1), 146. https://doi.org/10.35448/jte.v12i1.4442

Mukhdar, M., 2014. Analisis Faktor-Faktor Yang Mempengaruhi Impor Beras Di Indonesia. Skripsi. Universitas Islam Negeri Alauddin Makassar.

Musyaffa, A. S. and Sri, S. 2017. Pengaruh JumlahUang Beredar, Inflasi dan Suku Bunga Terhadap Nilai Tukar Rupiah Terhadap Dollar. Jurnal Administrasi Bisnis, 50(4), pp. 19-24.

Natsir, M., Fakriah and Ayuwandirah. 2016. Analisis Variabel Makroekonomi terhadap Indeks Saham Syariah Indonesia dengan Metode Pendekatan Vector Autoregegression'. Jurnal Ekonomi dan Bisnis, 15(1), pp. 10091010. doi: 10.1093/oseo/instance.00217122.

Paipan, S. 2020. Determinan Ketergantungan Impor Beras Di Indonesia (Determinants Of Rice Import Dependency In Indonesia). Jurnal Ekonomi \& Kebijakan Publik. Vol. 11 No. 1, 53-64.

Rachmanti, A. Riyadi \& Suharmanto. 2016. Pengaruh Inflasi dan Nilai Tukar Rupiah terhadap Impor Kedelai Di Jawa Tengah (Periode 2001-2013). Journal of Business Studies (JOBS), 185-196. http://dx.doi.org/10.32497/jobs.v1i2.654

Sadono Soekirno. 2009. Mikro Ekonomi Teori Pengantar. PT. Raja Grafindo Persada: Jakarta.

Sulaiman, M. 2019. Pengaruh Inflasi, Ekspor Netto dan Cadangan Devisa Terhadap Nilai Tukar Rupiah Terhadap Dollar AS. Prosiding. SATIESP

Zaeroni, R., \& Rustariyuni, S. D. 2014. Pengaruh Produksi Beras, Konsumsi Beras dan Cadangan Devisa Terhadap Impor Beras di Indonesia. E-Jurnal EP Unud, 5(9), 993-1010. 